\title{
Improving Students Ability in Mathematical Problem Solving Through Problem Based Learning Model in Tenth Grades State Senior High School 7 of Medan
}

\author{
Reza Handika Winata Lubis \\ Postgraduate Program \\ Universitas Negeri Medan \\ (UNIMED) \\ Medan, Indonesia \\ handikareza10@gmail.com
}

\author{
Edi Syahputra \\ Postgraduate Program \\ Universitas Negeri Medan \\ (UNIMED) \\ Medan, Indonesia
}

\author{
Pargaulan Siagian \\ Postgraduate Program \\ Universitas Negeri Medan \\ (UNIMED) \\ Medan, Indonesia
}

\begin{abstract}
This research aimed to determine that improving the mathematical problem solving ability of students through the PBL model is better than traditional learning. This research is a quasi experimental research. Sampling method is using random sampling method that is from tenth grade at State Senior High School 7 of Medan selected two classes as sample which subjected to random treatment of one as control class that is $\mathrm{X} 2$ and the other as experimental class that is X5. Eksperimental class is using PBL model and control class is using traditional learning. Inferensial statistic analysis was performed by Independent Sample t-Test. The math subject is system of linear equations with two variables. Based on the research, it was found that the significance value for mathematical problem solving ability in the experimental and control classes is 0.00 . Because $0.00<0.05$ then $\mathrm{HO}$ is rejected, So improving the mathematical problem solving ability through the PBL model is better than traditional learning. It was concluded that improving the mathematical problem solving ability through the PBL model is better than traditional learning.
\end{abstract}

Keywords: problem solving, $P B L$

\section{INTRODUCTION}

Problem is the gap between expectations with reality, between what they want or what is intended with what is happening or facts. The problem is a creation, in which an individual who faces it felt the need to solve or want to solve [1]. The students' mathematical problem solving abilities in PISA and TIMSS did not show good performance, and was below the average of international mathematics problem solving abilities in both test [2]. According to the NCTM [3] that the problem-solving ability is not just a goal of learning mathematics but also a major tool to perform or work mathematically.

Traditional methods of teaching mathematics have been found to be very defective and full of many inadequacies that do not allow students to actively construct their own mathematical knowledge [4]. Failures in school mathematics are largely associated with teaching traditions that are Not in accordance with the way most students learn [5]. Kwon, Park \& Park [6] concluded that traditional math education was intended to focus mostly on convergent thinking in which a student memorized existing mathematical rules and theorems and then applied them to problems to find one exclusive solution rather than to apply these rules and theorems in new and different ways.

The low ability of mathematical problem-solving is due to the use of traditional learning. Therefore, the solution needed to improve these higher order thinking skills is the use of an effective learning model. Concretely learning model can be implemented to improve students ${ }^{\text {ee }}$ high-level thinking ability in solving mathematical problem [7]. Moffit [8] said that the problem-based learning is an approach to learning that uses real-world problems as a context for students to learn about critical thinking and problem solving skills as well as to acquire the knowledge and concepts are the essence of the subject matter. Problem-based learning helps students develop Reviews their thinking and problem solving skills, learn authentic adult roles, and Become independent learners [9].

\section{Mathematical Problem Solving AbILIT}

Mathematical problem solving as the process of interpreting a situation mathematically, the which usually involves several iterative cycles of expressing, testing, and revising mathematical interpretation and of sorting out, integrating, modifying, revising or refining clusters of mathematical concepts from various topics within and beyond mathematics [10]. In the discipline of mathematics, the use of problem solving skills has been extremely important and highly influential. Problem solving is the foundation of all mathematical and scientific discoveries ". In the disciplines of mathematics using problem solving skills have a very important influence. Problem solving is the foundation of all mathematics and the process of discovering new knowledge [11]. 
In this study, we followed the features developed by Polya. Polya [12] there are four steps in solving the problem, namely: (1) understand the problem: in this activity is to formulate: what is known, what is asked, whether the information sufficient, condition (condition of) what should met, restate the original problem in a more operational (solvable). (2) planning the solution: the activities carried out in this step is trying to find or recall issues you've solved that has similarities with the properties that will be solved, look for patterns or rules, draw up resolution procedures. (3) implement the plan: the activities in this step are performs the procedures that have been created in the previous step to the settlement. (4) to re-examine the procedures and results of the settlement: activities in this step is analyzing and evaluating whether the procedures applied and the results obtained are correct, whether there are other procedures that are more effective, whether procedures have created can be used to solve similar problems, or whether the procedures generalizations can be made.

\section{Problem Based Learning (PBL)}

Problem-based learning is a learning approach where students work on authentic problems with a view to construct their own knowledge, develop inquiry and higher level thinking skills, and develop independence and confidence [9]. Problem-based learning model can be interpreted as a series of learning activities, with emphasis on the process of resolving the problems faced scientificall [13].

There are five stages of PBL: (1) student orientation at issue; (2) organize the students to learn; (3) guiding the investigation of individual and group; (4) develop and present the work and (5) analyze and evaluate the problem-solving process [14]. Advantages of problem-based learning: 1) Classes are student-centered instead of being teacher-centered. 2) This learning model develops self-control instudents. It teaches making plans prospectively, facing realities and expressing emotions. 3) This model enables students to see events multidimensionally and with a deeper perspective. 4) It develops students" problem-solving skills. 5) It encourages students to learn new materialsand concepts when solving problems. 6) It develops sociability levels and communication skills of students by enabling them to study andwork in a team. 7) It develops students"e high level thinking/critical thinking and scientific thinking skills. 8) It unites theory and practice. It allows students both to merge their old knowledge with new knowledge and to develop their judging skills ina specific discipline environment. 9) It motivates learning for both teachers andstudents. 10) Students acquire the skills of time management, focusing, data collection, report preparation and evaluation [15].

\section{METHOD}

\section{A. Sample and Data Analysis}

This research was a quasi experimental research. Sampling method is using random sampling method that is from tenth grade at State Senior High School 7 of Medan selected two classes as sample which subjected to random treatment of one as control class that is $X_{2}$ and the other as experimental class that is $X_{5}$ which consists of 64 students. Eksperimental class is using PBL model and control class is using traditional learning.. The instrument of the research using essay test which consists of a test of mathematical problem solving ability has 5 questions. Both of test given previously and after doing that, this thing is done to get impove in the mathematical ability. Data analysis is begun by determine normalized gain on ability problem solving students ${ }^{\text {ee }}$ mathematics for experiments and control class. To do that is using Meltzer Formula [16].

$$
<\mathrm{g}>=(<\mathrm{Sf}>-<\mathrm{Si}>) /(100-<\mathrm{Si}>)
$$

where $<\mathrm{Sf}>$ and $<\mathrm{Si}>$ are the final (post test) and initial (pre test). Criteria is defined as: (a) $(<\mathrm{g}>)>0.7$ is "High-g"; (b) 0.7 $\geq(<\mathrm{g}>) \geq 0.3$ is "Medium-g"; (c) $(<\mathrm{g}>)<0.3$ is "Low-g". Next step are normality and homogeneity test on normalized gain that normalization of each by using Kolmogorov - Smirnov test (K-SZ) and Leneve test. For testing hypothesis is done different test on gain normalized data either problem solving ability. All of counting are using software Microsoft Excel 2007 and IBM SPSS 23.0. Hypothesis testing using independent sample t-test through gain score of mathematical problem solving ability

\section{B. Hypothesis Testing}

Hypothesis testing using independent sample t-test through gain score of mathematical problem solving ability. The Null Hypothesis is improving the mathematical problem solving ability of students through the PBL model is same as traditional learning and the Alternative Hypothesis is improving the mathematical problem solving ability through the PBL model is better than traditional learning by significance $(\alpha)=0.05$. if significance score $<\alpha$, then Null Hypothesis is rejected $[17,18]$.

\section{RESULTS}

After using Microsoft Excel 2007, the data obtained in this study is derived from the pre-test and post-test on the subject in system of linear equations with two variables. The mathematical problem solving ability scores obtained from the test are presented in Table 1 and Table 2 as follows: 
TABLE 1. Test Result and Gaining Scores of Mathematical Problem Solving Ability in Experimental Class

\begin{tabular}{|c|c|c|c|c|c|}
\hline \multirow[b]{2}{*}{ Subject } & \multicolumn{4}{|c|}{ Score } & \multirow{2}{*}{ Criteria } \\
\hline & $\begin{array}{l}\text { Pre } \\
\text { Test }\end{array}$ & $\begin{array}{l}\text { Post } \\
\text { Test }\end{array}$ & Gain & $\langle g\rangle$ & \\
\hline SE-19 & 69.23 & 92.31 & 23.08 & 0.75 & High-g \\
\hline SE-31 & 69.23 & 92.31 & 23.08 & 0.75 & High-g \\
\hline SE-12 & 66.15 & 89.23 & 23.08 & 0.68 & $\begin{array}{c}\text { Medium- } \\
\mathrm{g}\end{array}$ \\
\hline SE-23 & 66.15 & 89.23 & 23.08 & 0.68 & $\begin{array}{c}\text { Medium- } \\
\text { g }\end{array}$ \\
\hline SE-32 & 66.15 & 89.23 & 23.08 & 0.68 & $\begin{array}{c}\text { Medium- } \\
\mathrm{g}\end{array}$ \\
\hline SE-29 & 64.62 & 87.69 & 23.07 & 0.65 & $\begin{array}{c}\text { Medium- } \\
\mathrm{g}\end{array}$ \\
\hline SE-09 & 64.62 & 87.69 & 23.07 & 0.65 & $\begin{array}{c}\text { Medium- } \\
\mathrm{g}\end{array}$ \\
\hline SE-21 & 63.08 & 86.15 & 23.07 & 0.62 & $\begin{array}{c}\text { Medium- } \\
\mathrm{g}\end{array}$ \\
\hline SE-07 & 63.08 & 86.15 & 23.07 & 0.62 & $\begin{array}{c}\text { Medium- } \\
\mathrm{g}\end{array}$ \\
\hline SE-17 & 63.08 & 84.62 & 21.54 & 0.58 & $\begin{array}{c}\text { Medium- } \\
\text { g }\end{array}$ \\
\hline SE-11 & 63.08 & 84.62 & 21.54 & 0.58 & $\begin{array}{c}\text { Medium- } \\
\mathrm{g}\end{array}$ \\
\hline SE-03 & 61.54 & 83.08 & 21.54 & 0.56 & $\begin{array}{l}\text { Medium- } \\
\text { g }\end{array}$ \\
\hline SE-25 & 61.54 & 81.54 & 20.00 & 0.52 & $\begin{array}{c}\text { Medium- } \\
\mathrm{g}\end{array}$ \\
\hline SE-15 & 61.54 & 81.54 & 20.00 & 0.52 & $\begin{array}{c}\text { Medium- } \\
\mathrm{g}\end{array}$ \\
\hline SE-14 & 61.54 & 80.00 & 18.46 & 0.48 & $\begin{array}{c}\text { Medium- } \\
\mathrm{g}\end{array}$ \\
\hline SE-24 & 60.00 & 80.00 & 20.00 & 0.50 & $\begin{array}{c}\text { Medium- } \\
\mathrm{g}\end{array}$ \\
\hline SE-10 & 60.00 & 80.00 & 20.00 & 0.50 & $\begin{array}{c}\text { Medium- } \\
\mathrm{g}\end{array}$ \\
\hline SE-18 & 60.00 & 78.46 & 18.46 & 0.46 & $\begin{array}{c}\text { Medium- } \\
\mathrm{g}\end{array}$ \\
\hline SE-01 & 60.00 & 76.92 & 16.92 & 0.42 & $\begin{array}{c}\text { Medium- } \\
\mathrm{g}\end{array}$ \\
\hline SE-30 & 60.00 & 76.92 & 16.92 & 0.42 & $\begin{array}{c}\text { Medium- } \\
\mathrm{g}\end{array}$ \\
\hline SE-08 & 60.00 & 76.92 & 16.92 & 0.42 & $\begin{array}{c}\text { Medium- } \\
\text { g }\end{array}$ \\
\hline SE-22 & 60.00 & 76.92 & 16.92 & 0.42 & $\begin{array}{c}\text { Medium- } \\
\mathrm{g}\end{array}$ \\
\hline SE-04 & 58.46 & 75.38 & 16.92 & 0.41 & $\begin{array}{c}\text { Medium- } \\
\mathrm{g}\end{array}$ \\
\hline SE-16 & 58.46 & 75.38 & 16.92 & 0.41 & $\begin{array}{c}\text { Medium- } \\
\mathrm{g}\end{array}$ \\
\hline SE-13 & 58.46 & 75.38 & 16.92 & 0.41 & $\begin{array}{c}\text { Medium- } \\
\mathrm{g}\end{array}$ \\
\hline SE-27 & 58.46 & 75.38 & 16.92 & 0.41 & $\begin{array}{c}\text { Medium- } \\
\mathrm{g}\end{array}$ \\
\hline SE-26 & 55.38 & 73.85 & 18.47 & 0.41 & $\begin{array}{c}\text { Medium- } \\
\mathrm{g}\end{array}$ \\
\hline SE-28 & 55.38 & 73.85 & 18.47 & 0.41 & $\begin{array}{c}\text { Medium- } \\
\text { g }\end{array}$ \\
\hline SE-06 & 55.38 & 73.85 & 18.47 & 0.41 & $\begin{array}{c}\text { Medium- } \\
\mathrm{g}\end{array}$ \\
\hline SE-20 & 53.85 & 72.31 & 18.46 & 0.40 & $\begin{array}{c}\text { Medium- } \\
\text { g }\end{array}$ \\
\hline SE-02 & 53.85 & 72.31 & 18.46 & 0.40 & $\begin{array}{l}\text { Medium- } \\
\mathrm{g}\end{array}$ \\
\hline SE-05 & 46.15 & 67.69 & 2.54 & 0.40 & Med.-g \\
\hline
\end{tabular}

TABLE 2. Test Result and Gaining Scores of Mathematical Problem Solving Ability in Control Class

\begin{tabular}{|c|c|c|c|c|c|}
\hline \multirow[b]{2}{*}{ Subject } & \multicolumn{4}{|c|}{ Score } & \multirow[b]{2}{*}{ Criteria } \\
\hline & $\begin{array}{l}\text { Pre } \\
\text { Test }\end{array}$ & $\begin{array}{l}\text { Post } \\
\text { Test }\end{array}$ & Gain & $\langle g\rangle$ & \\
\hline SE-26 & 75.38 & 93.85 & 18.47 & 0.75 & High-g \\
\hline SE-23 & 73.85 & 89.23 & 15.38 & 0.59 & $\begin{array}{l}\text { Medium- } \\
\mathrm{g}\end{array}$ \\
\hline SE-08 & 73.85 & 87.69 & 13.84 & 0.53 & $\begin{array}{c}\text { Medium- } \\
\mathrm{g}\end{array}$ \\
\hline SE-25 & 72.31 & 87.69 & 15.38 & 0.56 & $\begin{array}{l}\text { Medium- } \\
\text { g }\end{array}$ \\
\hline SE-32 & 72.31 & 87.69 & 15.38 & 0.56 & $\begin{array}{l}\text { Medium- } \\
\mathrm{g}\end{array}$ \\
\hline SE-14 & 70.77 & 86.15 & 15.38 & 0.53 & $\begin{array}{l}\text { Medium- } \\
\mathrm{g}\end{array}$ \\
\hline SE-15 & 70.77 & 86.15 & 15.38 & 0.53 & $\begin{array}{l}\text { Medium- } \\
\mathrm{g}\end{array}$ \\
\hline SE-16 & 69.23 & 86.15 & 16.92 & 0.55 & $\begin{array}{c}\text { Medium- } \\
\mathrm{g}\end{array}$ \\
\hline SE-17 & 69.23 & 86.15 & 16.92 & 0.55 & $\begin{array}{l}\text { Medium- } \\
\mathrm{g}\end{array}$ \\
\hline SE-18 & 66.15 & 83.08 & 16.93 & 0.50 & $\begin{array}{c}\text { Medium- } \\
\mathrm{g}\end{array}$ \\
\hline SE-11 & 66.15 & 83.08 & 16.93 & 0.50 & $\begin{array}{c}\text { Medium- } \\
\mathrm{g}\end{array}$ \\
\hline SE-03 & 64.62 & 81.54 & 16.92 & 0.48 & $\begin{array}{c}\text { Medium- } \\
\mathrm{g}\end{array}$ \\
\hline SE-31 & 64.62 & 80.00 & 15.38 & 0.43 & $\begin{array}{l}\text { Medium- } \\
\mathrm{g}\end{array}$ \\
\hline SE-15 & 64.62 & 78.46 & 13.84 & 0.39 & $\begin{array}{l}\text { Medium- } \\
\mathrm{g}\end{array}$ \\
\hline SE-27 & 63.08 & 78.46 & 15.38 & 0.42 & $\begin{array}{l}\text { Medium- } \\
\mathrm{g}\end{array}$ \\
\hline SE-13 & 63.08 & 78.46 & 15.38 & 0.42 & $\begin{array}{l}\text { Medium- } \\
\text { g }\end{array}$ \\
\hline SE-21 & 63.08 & 78.46 & 15.38 & 0.42 & $\begin{array}{l}\text { Medium- } \\
\mathrm{g}\end{array}$ \\
\hline SE-07 & 63.08 & 75.38 & 12.31 & 0.33 & $\begin{array}{l}\text { Medium- } \\
\mathrm{g}\end{array}$ \\
\hline SE-17 & 61.54 & 73.85 & 12.31 & 0.32 & $\begin{array}{c}\text { Medium- } \\
\mathrm{g}\end{array}$ \\
\hline SE-30 & 61.54 & 73.85 & 12.31 & 0.32 & $\begin{array}{c}\text { Medium- } \\
\mathrm{g}\end{array}$ \\
\hline SE-19 & 61.54 & 72.31 & 10.77 & 0.28 & Low-g \\
\hline SE-28 & 61.54 & 72.31 & 10.77 & 0.28 & Low-g \\
\hline SE-06 & 60.00 & 72.31 & 12.31 & 0.31 & $\begin{array}{c}\text { Medium- } \\
\mathrm{g}\end{array}$ \\
\hline SE-20 & 60.00 & 7077 & 10.77 & 0.27 & Low-g \\
\hline SE-02 & 60.00 & 70.77 & 10.77 & 0.27 & Low-g \\
\hline SE-05 & 60.00 & 70.77 & 10.77 & 0.27 & Low-g \\
\hline SE-12 & 58.46 & 69.23 & 10.77 & 0.26 & Low-g \\
\hline SE-22 & 58.46 & 69.23 & 10.77 & 0.26 & Low-g \\
\hline SE-04 & 58.46 & 69.23 & 10,77 & 0.26 & Low-g \\
\hline SE-16 & 56.92 & 58.46 & 1.54 & 0.04 & Low-g \\
\hline SE-09 & 56.92 & 58.46 & 1.54 & 0.04 & Low-g \\
\hline SE-29 & 55.38 & 58.46 & 3.08 & 0.07 & Low-g \\
\hline
\end{tabular}


After Using Microsoft Excel 2007 and IBM SPSS 23.0, the recapitulation and significance score of test results and gaining scores of mathematical problem solving ability is presented in Table 3 as follows:

TABLE 3. Recapitulation of Test Result Average and Significance in Mathematical Problem Solving Ability

\begin{tabular}{|c|c|c|c|c|c|}
\hline Class & $\begin{array}{c}\text { Pre test } \\
\text { average }\end{array}$ & $\begin{array}{c}\text { Post test } \\
\text { average }\end{array}$ & $\begin{array}{c}<\text { g }> \\
\text { averag } \\
\mathbf{e}\end{array}$ & Criteria & $\begin{array}{c}\text { Signifi } \\
\text { cance } \\
\text { score }\end{array}$ \\
\hline $\begin{array}{c}\text { Experimental } \\
\text { class }\end{array}$ & 60.58 & 80.53 & 0.52 & $\begin{array}{c}\text { Medium- } \\
\mathrm{g}\end{array}$ & \multirow{2}{*}{0.00} \\
\cline { 1 - 4 } $\begin{array}{c}\text { Control } \\
\text { class }\end{array}$ & 64.28 & 77.12 & 0.38 & $\begin{array}{c}\text { Medium- } \\
\mathrm{g}\end{array}$ & \\
\hline
\end{tabular}

According Table 3. the significance score is 0.00 . it show that significance score $<\alpha$. It means that Null Hypothesis is rejected. So, Alternative Hypothesis is accepted means improving the mathematical problem solving ability through the PBL model is better than traditional learning.

\section{DISCUSSION}

Padmavathy and Mareesh [19] Findings of the study revealed that problem based learning had effect in teaching mathematics and improve students understanding, ability to use concepts in real life. The results of this study shown that both mathematical problem solving ability who were taught by Problem Based Learning (PBL) is better than students taught with Traditional Learning. It can be proven by the results of the study. the $<\mathrm{g}>$ average of mathematical problem solving ability through PBL model (experimental class) is higher than students taught by Traditional Learning (control class), it is $0.52>0.38$. (Ajai. et al , 2013) [20] in his research showed that students taught using problem-based learning is achieved is significantly higher than those taught using the usual learning.

\section{CONCLUSIONS}

Based on the results and discussion it was concluded that improving the mathematical problem solving ability of students through the PBL model is better than traditional learning. In addition, this study proves that PBL model can improve mathematical problem solving ability.

\section{ACKNOWLEDGMENTS}

Thank you to all leaders and staff in Mathematics Education Postgraduate Program of UNIMED, Thank you to the Thesis Supervisors, and also thank you to Head of State Senior High School 7 of Medan.

\section{REFERENCES}

[1] Aydogdu, at al. 2004. A Research On Geometry Problem Solving Strategies Used By Elementary Mathematics Teacher Candidates. Journal of Educational and Instructional Studies in The World, Volume: 4, Issue: 1, Article:07 ISSN:2146-7463. Turkey: WJEIS.

[2] Wulandari, N. Ferry, \& Jailani. "Indonesian Studentse Mathematics Problem Solving Skill in PISA and TIMSS" in Proceeding of International Conference On Research, Implementation and Education of Mathematics And Sciences 2015, Yogyakarta State University, 17-19 May 2015.

[3] NCTM (2000). Principles and Standards for school mathematics. Reston, VA: National Council of Teachers of Mathematics.

[4] Dubinsky, E. (1991). ,Reflective Abstraction ${ }^{\text {ee }}$ in Advanced Mathematical Thinking. In D. Tall (Ed.), Advanced Mathematical Thinking (pp. 95-102). Dordrecht The Netherlands: Kluwer Academic.

[5] National Research Council. (1989). Everybody counts: A report to the nation on the future of mathematics education. Washington, D.C.: National Academy Press.

[6] Kwon, O. N., Park, J.S., \& Park, J.H. (2006). Cultivating Divergent Thinking in Mathematics through an Open-Ended Approach. Asia Pasific Education Review. 7, 51-61.

[7] Surya E. dan Syahputra E. 2017. Improving High-Level Thinking Skills by Development of Learning PBL Approach on the Learning Mathematics for Senior High School Students. International Education Studies. Vol. 10, No. 8; ISSN 1913-9020 E-ISSN 1913-9039, Published by Canadian Center of Science and Education.

[8] Rusman. 2011. Model - Model Pembelajaran Mengembangkan Profesionalisme Guru. Bandung: Raja grafindo.

[9] Arends, R. 2008. Learning To Teach. London: Student Library

[10] Kuzle, A. 2013. Patterns of Metacognitive Behavior During Mathematics Problem-Solving in a Dynamic Geometry Environment, International Electronic Journal of Mathematics Education, Vol. 8, No. 1.

[11] Vettleson Jr. 2010. Problem Solving Based Instuction in the High School Mathematics Classroom.

[12] Polya, G.1985. How to Solve It 2nd ed Princeton.University Press: New Jerse.

[13] Sanjaya, W. 2011. Strategi Pembelajaran Berorientasi Standar Proses Pendidikan. Jakarta: Kencana Prenada Media Group.

[14] Trianto. 2010. Mendesain Model Pembelajaran inovatif-progresif. Jakarta: Kencana.

[15] Akinoglu, O. 2007. The Effects of Problem-Based Active Learning in Science Education on Students ${ }^{\text {ee }}$ Academic Achievement, Attitude and Concept Learning, Turki :Eurasia Journal, 2007.

[16] Hake, R.R. 1999. Analyzing Change/Gain Score. Woodland Hills: Dept. Of Physics, Indiana University. [Online]. Tersedia: http://www.physics.indiana.du/ sdi/AnalyzingChang-Gain.pdf

[17] Syahputra, E. 2016, Statistika Terapan Untuk Quasi dan Pure Experiment di Bidang Pendidikan, Biologi, Pertanian, Teknik, dll. Medan: Unimed Press.

[18] Latan, H. 2014. Aplikasi Analisis Data Statistik untuk Ilmu Sosial Sains dengan IBM SPSS. Bandung: Alfabeta.

[19] Padmavathy and Mareesh. 2013. Effectiveness of Problem Based Learning In Mathematics. International Multidiciplinary e-Journal. VolII, Issue-I. ISSN : 2277-4262.

[20] Ajai, J. T. , et al. 2013. Comparison of The Learning Effectiveness of Problem Based Learning (PBL) and Conventional Method of Teaching Algebra. Nigeria: Journal of Education and Practice. Vol. 4 No. 1 ISSN 2222288x. 